\title{
Palomar by Italo Calvino: The (un)Covering of (un)Equivocal (un)Truth
}

\section{Franco Ricci}

Palomar, like Se una notte d'inverno un viaggiatore, is essence of a mature Calvino pure and unadultered - or at least as the author wishes to be remembered. The casual reader of Calvino is accustomed to the author's solving of unsolvable puzzles, his delving into the essence of being, his faith in the introspective powers of ratiocination as demonstrated in such works as Le cosmicomiche, Ti con zero, Il castello dei destini incrociati. Yet an undercurrent of discontent and negativity belies the speculations of Calvino-Palomar. Queries are merely posited; the answers are never forthcoming; reason is not triumphant and man is inevitably defeated by his own miopic meditations. Is the author's faith in the power of reason waning? Can rationality triumph in an irrational world? Is the exercising of reason futile and purposeless? Is Calvino subverting the natural order while submitting to his own cynicism? Since ratiocination in Palomar does not liberate but instead ensnares and shackles (reason, it would seem, produces alienation), is the world in need of automatons - mindless, senseless, lifeless creatures - the one dimensional men Calvino described in the Fifties and early Sixties (La formica argentina, La speculazione edilizia, La nuvola di smog, and La giornata di uno scrutatore) and of whom he still writes. Is Palomar, then, a product of the author's own existential misgivings, or a comment on man's being in the world?

In Palomar Calvino remains, as always, precipitously close to the void. Thought overrides action, the self remains obdurate in its lethargy. The universe is a puzzle; a matrix of dissembled parts whose logical order paradoxically befuddles the astute observer who finds no rest in its perfect imperfection. It would seem that the machinations of the mind no longer serve the purpose of discovery for indeed the book's end does not coincide with an epiphany. This sort of misanthropic intellectualism is not new to Calvino. An existential program of contortioned, negative neopirandellian introspection (or "pessimismo programmatico") is 
outlined in many of his early essays. ${ }^{1}$ The many characters of his tales also consistently question the validity of the world in which they reside, in this sense becoming anomalies of human destiny, models of possible, projected rapports with an often hostile environment. Their struggle towards individual viability is colored by an absurdist disposition towards emotional lethargy, passive nihilism, and solitude. They are victims stripped to the human minimum, spectators recording the objective data which envelops them.

Pin (Il sentiero dei nidi di ragno) is the first victim. He is baffled by the world of men, war, and reality, thus for him events become "un gioco dentro l'altro che non si riesce mai a capire qual è il gioco vero" (p. 49). He is followed by a retinue of protagonists who pass judgement on a world which fails to meet their conception of the ideal, yet cognizant that their ideal is fatuous. From this nihilist stance spring the imagos of Calvino's universe. The paladins of Il cavaliere inesistente search for "l'angolo giusto per vedere le cose" (p. 69). Questioning the fiction of life they divine its essence in an attempt to discover "la geometria segreta, l'ordine, la regola per capirne il principio e la fine" (p. 85). A condition of despair drives the Baron (Il barone rampante) into the trees, while the protagonists of La formica argentina, La nuvola di smog, and Marcovaldo assume a spectator stance, looking for signs of hope, searching for the "courage to be," ultimately confronting the stark futility of peering off into the "whiteness" of space (or blank page). The characters of I racconti face experiences which are inchoate and incomprehensible, lacking order or form. In the cosmic tales (Le cosmicomiche, Ti con zero, La memoria del mondo) Calvino relies upon irony, incongruity, paradox, and farce in a cathartic attempt to broach the disembodied status of man's tragicomic existence. Contradiction and dualism now emerge as the dynamic principles that inform the work of Calvino, eventually engendering the dilemma of existential choice. ${ }^{2}$ The characters of Il castello dei destini incrociati, and La taverna dei destini incrociati are burdened with the weight of this dilemma; though they may choose their personal existence, their private story, they are strapped within the pattern set by the tarot cards. Marco Polo too, in Le città invisibili, elevates personal desire to the limit, erecting mirages in a wasteland in an attempt to appease his yearning for a world not bereft of meaning. And though at book's end a liberating philosophy is proffered, it offers bitter, inconsolable recourse for the spirit. In Se una notte d'inverno un viaggiatore the reader-protagonist is caught-up within a catalogue of possible destinies, a literary game of chance, inevitably linked to the death 
impulse. He postulates wryly: "Tu sai che il meglio che ci si può aspettare è di evitare il peggio" (p. 94).

Yet while Calvino in the past has attempted to fill this existential void through reason and conjecture, through fantasy and realism, through structuralism and semiotics, in an attempt to give meaning to the world, Palomar's subjective, and, above all, private responses to the universe reinforce the validity of the void as sole controlling image. Palomar, in this sense, is an elaborate Voltairian game, a pre-empted liberating gesture, a synthesizing pretext in the scheme of calvinesque logic. In essence, we may view these stories as samples of a larger discourse by the author or philosophical category. They represent, in this sense, the completion of a whole, and must be interpreted as exempla of acts of reading, writing, description, and meditation. "Rendono conto," states the author in an explanatory note to the Table of Contents, "d'esperienze di tipo piú speculativo, riguardante il cosmo, il tempo, l'infinito, i rapporti tra l'io e il mondo, le dimensioni della mente. Dall'ambito della descrizione e del racconto si passa a quello della meditazione."

An ontological symmetry (both within the literary universe of Calvino and that of Palomar) is prescribed and preserved in the text through a deliberate unity of approach which divides the tales in three sections or books: 1. Le vacanze di Palomar; 2. Palomar in città; 3. I silenzi di Palomar. Each section further divides its tales into three topical groupings. For example, book 2., Palomar in città, contains the sub-groups: 2.1 Palomar sul terrazzo; 2.2 Palomar fa la spesa; 2.3 Palomar allo zoo, where the first number identifies the subsection within a major book or category: 1., 2., or 3., and the second locates the subsection's sequential order within the larger book. Each tale is similarly coded: "Il gorilla albino," numbered 2.3.2., is in the second book (2.), third subsection (.3), and is the second story (.2) of this subsection. The gamut, however, is much more ample as the author introduces a continuous series of thematic connotations by further overcoding the numbers within intertextual frames (generic rules). Each number thus also frames the book/sub-section/tale within a defined, though flexible, semantic field. These topical frames represent sememic categories of: 1. Description; 2. Fabulation; and 3. Meditation. "Lettura di un'onda," for example, numbered 1.1.1., is in the first book (1.), first section (.1), and is the first story (.1). The overcoded number 1 , however, also identifies it as a purely descriptive mosaic concerned primarily, in this instance, with a visual experience. The existence of this sub-coded transformation 
process working at different levels of signification, allows us to read "Un chilo e mezzo di grasso d'oca," numbered 2.2.1., as the first tale of the second subsection of the second book, while at the same time interpreting a strategy which generates a fabula (2) that transforms a visual, temporal, inanimate object ("il grasso d'oca") into a discursive structure (1). The final tale, "Come imparare a essere morto," numbered 3.3.3., elevates this correlative model and language to its most transparent stage of logical abstraction. Once the trajectory of these tales has been ascertained, it becomes evident that we are witness to a movement from the particular to the general, from the concrete to the abstract. The purpose of this reading strategy is decidedly exemplary if not conspicuously illustrative. The reader is moving step by step through a hierarchical scheme of displacement. A "shallower" level of descriptive structure (1.) is expanded to include narrative situations (2.) which eventually render themselves redundantly isotopic but reconstitute themselves as metaphysical concepts (3.). The contiguity which supports this metonymic transference relies upon a semantic shift from the empirical (the precise, but elementary description of objects based on an oppositional code) to the unworldly, unifying character of constant signification (philosophy). As such Palomar represents an obsessive attempt to organize one's universe using the medium of literary strategies, while at the same time posits an effort to go beyond language and signification as the shaper of one's world.

Calvino is a master of obsession. A perfidious idea leads to megalomaniac investigation and conjecture tempered by the foreboding knowledge of non-existence and superfluity. Each tale in Palomar is a divestiture, a reduction of the act of writing to the kernel idea and words around which tales may be written. Yet far from pretending closure, the text imposes openess, momentaneity, and differentiation. Calvino's prose has always been by definition structurally formalistic. The pleasure in reading Calvino is derived from disambiguating the deception of his subversive strategies. For these reasons these tales do not endear their reader in a traditional sense, nor do they allow replication in the textual strategy. Rather, they alienate and disturb. Tranquillity is impossible. As a literary technician, then, Calvino is a master of that strategic compliance necessary between reader and writer in order to produce that same discomfort which originally motivated the tales.

Towards this end the language of Palomar is stark and precise; an apology of refractive intellectualism. The world is constructed 
of words and decipherible signs whose conciseness belies their Saussurian conventionality yet which seem to fit together so snugly, so rationally, that one marvels at the complacent mastery with which Calvino strings together his free floating thoughts. This showcase of verbal prowess and precision in description, however, tends to leave the reader cold. In a passage which rigorously manifests the author's attempt at logocentric effacement we read:

Questo negozio è un dizionario; la lingua è il sistema dei formaggi nel suo insieme: una lingua la cui morfologia registra declinazioni e coniugazioni in innumerevoli varianti e il cui lessico presenta una richezza inesauribile di sinonimi, usi idiomatici, connotazioni e sfumature di significato, come tutte le lingue nutrite dall'apporto di cento dialetti. $\grave{E}$ una lingua fatta di cose; la nomenclatura ne è solo un aspetto esteriore, strumentale; ma per il signor Palomar impararsi un po' di nomenclatura resta sempre la prima misura da prendere se vuole fermare un momento le cose che scorrono davanti ai suoi occhi." (pp. 75-76)

The language, in this passage, acts as an accessory medium which permits temporary ingress to the reality which subtends it, while at the same time threatens, through its preciseness to subvert the multiformity of the system it deciphers. As a rule-governed activity, the range of this system of discourse is small and never moves towards completion, instead it focuses on in-completeness, and is restricted to the service of didacticism. The major fault of the text is precisely this dependence upon didactic method. It is this "willto-methodology" that portends its sterility. What is lacking in the language of this text is the emotion of the trilogy, the melancholy of Marcovaldo and the ribald humor of Qfwfq. Though intellectually compelling as Le città invisibili, the words purposefully tend towards self consumption mired as they are in their own signification, signifiers of meaninglessness. In this sense Palomar is heir to Calvino's existential-phenomenological individualism and descriptive analysis of the Fifties ("Una pietra, una figura, un segno, una parola che ci arrivano isolati dal loro contesto sono solo quella pietra, quella figura, quel segno o parola: possiamo tentare di definirli, di descriverli in quanto tali, e basta"; Palomar, "Serpenti e Teschi," p. 99), while at the same time caught up in a poststructuralist world of reductive, self-referential language and logic ("una rete d'analogie," p. 100), imbued with pessimism:

Forse perché il mondo intorno a lui si muove in modo disarmonico ed egli spera sempre di scoprirvi un disegno, una costante. Forse perché lui 
stesso sente di procedere spinto da moti della mente non coordinati, che sembrano non aver niente a che fare l'uno con l'altro e che è sempre piú difficile far quadrare in un qualsiasi modello d'armonia interiore. ("La corsa delle giraffe," p. 81).

By focusing on particulars, Calvino-Palomar is discounting plenitude. Compensation for this lack is attempted through "supplemental" ratiocination. Yet though wishing to complete a universe already ideally and metaphysically complete in itself, his speculations are presented as exterior, if not foreign to the nature of the universe itself. Herein lies the paradox. Though CalvinoPalomar wishes, indeed strives, to rationally order the universe ("a tenerne presenti tutti gli aspetti insieme... estendere questa conoscenza all'intero universo," "Palomar sulla spiaggia," p. 10), in the end he may only defer his own presence within the cosmos by postulating his own absence. Reasoning and speculation may now be seen as a substitute for the protagonist's ultimate object of desire, the ultimate Other, which is the void. His discomforting conclusions (if they may be called such) provide the illusion, the subaltern instance of his own presence in a reductive universe. They provide no relief, however, no haven of respite, and are mere supplements to a growing ledger of enigmatic addenda. The world, it seems, is a simulacrum (an ideal possibility) of ontological security, a mere copy of something unintelligible, or which has never been said. ${ }^{3}$ Calvino, by manifesting the introspective, ratiocinative nature of Palomar under the guise of street philosopher, is not revealing anything new. He is, interestingly enough, though, naming for the first time the neurosis which afflicts his characters and has been the hallmark, we feel, of his literary enterprise.

Calvino's narrators have been termed Voltairian storytellers; ironic, solitary spectators; cynical, idiosyncratic and amusing observers. His narrative has been qualified as neorealist, fantastic, surrealist, baroque, and kafkesque. Yet where once Marcovaldo represented the "Buon Selvaggio" seeking unity with Nature, the sense of separateness and estrangement which his escapades effuse render tragic the extreme subjectivity of the figure. And though Qfwfq's peripatetic meanderings through the cosmos may strike the reader at first as fantastic, comic fiction, upon closer reading one notices the saddened, cynical smile of a character whose logic and loquacity only serve to disguise the pervasive fear of emptiness and solitude. Similar paradoxical constructs may be formulated concerning all of Calvino's characters. In Palomar, 
however, this attitude is openly vented.

Like the model reader of Se una notte d'inverno un viaggiatore Palomar is an obsessed, subjective reader seeking identity ("validity") in the macrocosm (text) before him. The labyrinth of the universe (as the truncated novels of Se una notte d'inverno un viaggiatore) is a pretext engendering the desire for discovery; its exploration is the achetype of the discoverer. Palomar's fascination with the physical world emanates from its tacit invitation to exploration (it's there in a Hirschian sense therefore it must conceal a meaning!). His subjective response, or search for significance, guarantees his evasion from an abhorrent reality ("le spiaggeimmondezzaio dei continenti-cimiteri," "La spada del sole," p. 19) and allows him to enter the privileged world of the written word which is quite distinct from the chaos before him. ${ }^{4} \mathrm{He}$ is endowed with acute philosophical acumen and astute intelligence. Palomar, clearly Calvino's alter ego, is seeking a point of differentiation or point of reference from which to postulate further pluri-probable states of being. His calculations to this end of creating and preserving the self though precise, patient, and, we venture, infallible, are somewhat redundant, if not self-referentially inconclusive. Triggered as they are by phenomenological stimuli, these observations present themselves as spontaneous, indeed transparent representations of thought. Palomar's attempts to discern a constant, unaffected meaning present in the regularly evolving models of the universe before him auger the felicity conditions necessary to grasp that unifying content of the whole known as truth. The elucidation of truth, however, implies evanescence. Palomar's attempts to "hold on" to the fleeting waves of the sea, to the all encompassing vision of a sunbather's breast, to the penetrating significance of a blackbird's silence, necessarily undo themselves at the moment he creates the impression of having achieved the ineffable sublime. But of course: his new model involves an illusion. Fundamental to the interpretive strategy of Palomar, then, is the metaphor of the unlimited, textual labyrinth.

A controlling image and constant in all of Calvino's writings, the labyrinth has evolved from surmountable obstacle to inconsequential, if not illusory, state of being. ${ }^{5}$ Palomar's entire existence is a reader's labyrinth of pluriprobable and multifaceted possible worlds which he carries within himself as a constant, though counterfactual, state of being. It is the privileging of this subjectivist, perverse, and idiosyncratic reading of the universal labyrinth that renders him disconsolate and self-consciously defensive. This pattern of determined indeterminacy that he sustains also limits 
his interpretive integrity. By placing himself (speaking subject) at the forefront of the linguistic experience (a reversal of structuralism which discounts the subject yet privileges his phonocentrism), his observations appear as pre-conceived models (a poetics?). This ideology is not only overtly limited, but indeed fractious. The disassembled world is never reconstituted. Access through these stories, then, to a clear and tenable understanding of their subject matter is difficult if not impossible. Palomar's acts of attempted unlimited semiosis seek classical, intrinsic values (truth), in a system of ever changing semiotic frames. At the same time his specific acts of representation foreground differentiation and a componential deconstruction of these values. The work, then, is a para-literary, para-philosophical attempt to spin tales without privileging events and posit an ideal normative concept of the world, while defrocking and subverting traditional semiological structuralism. The material of this reality is fiction; that labyrinthine network of limitless interrelations whose constructs expand towards a totality which is near to the infinite while necessarily stopping short of it. As reader of these fictions, Palomar identifies with their realities in order to become a part of them, in order to understand and derive pleasure from the union. No boundaries divide him from his experience. No separateness exists between himself and the void. Palomar's death at book's end may be viewed as a type of transcendental fusion. He has emptied himself of those constituent attributes which structure being and has totally effaced himself in a symbiotic union with the universe. This undifferentiated matrix of self and object, of text and reader, of universe and observer, embodies the nexus of the reader's abstractive, creative process and constitutes an attempt to perceive the emptiness/fullness behind the phenomenological world of the verbal labyrinth. This vantage would seem to contradict radically the process (or at least attempted process) of logicity governing the ratiocination of Palomar. Yet rationality has been defeated by modernism; and plurality has subverted positivism. Though Calvino may indeed postulate an existence beyond the labyrinth, it nevertheless remains a locus amoenus for his imagination.

Palomar, then, is not a deification of human consciousness unsuccessfully attempting to save itself from annihilation. He is instead the harbinger of some ultimate cosmic consciousness, an unqualified prophecy of man's destruction in an epoch when Reason and History have been buffeted into submission by the absurdity of current events. He is most importantly, however, also 
the logical, and we feel, legitimate outcome of a trajectory which began in the Partisan woods of Pin. Since the grammar of the individual's choice in Calvino has always been personal, the interpretation of the world is ultimately self-referential. This attitude explains the extreme solitude inherent in all of Calvino's works. Since characters are incapable of establishing an un-mediated rapport with others, they are doomed to live their own lonely, redundant, and self-serving miopic strategies. It stands to reason that this existence is a precarious one since interaction with reality has been pre-empted by a defensive screen of objective neutrality and detachment from the world in order to better discern its characteristics. This attitude naturally engenders an effacement of the Other since the protagonists rely solely upon their own observations and are attempting to return, ideally, to a prelinguistic stage of psychological development (or "stade du miroir"), whereupon they encounter the world devoid of, yet ostensibly shackled to, a linguistic determinism. Once again Calvino has effaced the Other in Palomar. The tales are without plots or real interlocutors. The protagonist too is completely effaced since the message of Palomar is indissolubly linked to his own status as non-communicative, but ratiocinative entity. This is perhaps both the beauty and tragedy of characters such as the Viscount, the Baron, Amerigo Ormea, Qfwfq, Marco Polo, Palomar, indeed of Calvino the solitary author. All have chosen to reside in private microcosms of unmediated knowledge and experience which comprise - while at the same time distance - the universe they abhor and love. ${ }^{6}$

This distance/proximity is implicit in the metaphor of the name Calvino has appropriately ascribed to his character. Palomar calls to mind the famous telescope located on Mount Palomar in Southern California. It too scrutinizes the heavens and casts a roving, but fixed eye upon eternally itinerent celestial bodies. Limited by its optic focal length (in a sense "miopic" like Palomar) to a defined perspective and range of view, its field of vision produces meaning relevant only to a circumscribed spatial field - therefore predetermined - and evokes a concept of center; i.e. a scientific political theological structural feature that stabilizes the panoply of differentiated elements in the system. Palomar, too, as homo significans, is a wandering eyeball endowed with an extraordinary capacity to process information into a rigorously precise, exacting, and demystifying space and categories of specificity. Yet his grammar for the world does not function. As scrutinizer of the cosmos he may only know the reality of his delimited frontier. In a god- 
less universe no contact may be made with an all encompassing author; knowledge is impossible. Reading, then, is not a liberating gesture just as ratiocination only augers entrapment and literature may only suspend precarious, temporary bridges which await destruction. Every end is implicit in each beginning; Palomar's closure-avoiding models involve an illusion; the creation of an immediate presence (his own or otherwise) necessarily implies the axiological paradigm of an absence. By deriding its own inherent inconsistencies, Palomar tragically exposes the folly of attempting to escape the parameters of his own epistemological system.

In the final meditation of the work, "Come imparare a essere morto," Palomar learns that he may indeed only play at reassembling a fragmentary experience, or he may continue disassembling broader syntactic unities with the fascinating consequence, however, of self-destruction. This as an aporetical moment; he is at opposite extremes of a scale which spans the void. Speculating upon the finality/continuity of death in a deductive process which recalls Zeno's argument of the arrow, Palomar concludes that any present instant is not static or given ("ogni istante, a descriverlo, si dilata tanto che non se ne vede piú la fine," p. 128), but rather is a product of the relationship between present and future instants, between present and future thoughts. Things (himself, the universe . . .) must, therefore, at each instant be intrinsically different from what they would be if they were not changing. Becoming, in this sense, is a constant experience of dying. Only the dead may find illuminating solace in their natural state of irresponsibility and sublime detachment. His adventure must now draw to a Foucaultian close, as indeed it does since the only real nonsensical yet irreducible meaning is absence. Yet his death is not the defeat of reason, just as defeat in a chess match is a predestined, though not ignoble, consequence of the game. ${ }^{7}$ It is instead the unfortunate deification of the mortal, preemptory quest for wholeness, of man's dream of full presence. Calvino, Twentieth Century master of the "conte philosophique" is now pure "philosophe." And indeed, though what we may be sure of is very little (if anything at all), like Palomar, we must endure to the very end.

\section{University of Ottawa}

NOTES

1 See especially "Il midollo del leone" (1955), "Il mare dell'oggettività" (1959), 
"La sfida al labirinto" (1962), "Un'amara serenità" (1963), all of which are collected in Una pietra sopra (Torino: Einaudi, 1980). Calvino's cerebralism is a natural corollary to Pirandello's existential considerations on man's often sterile, always incongruous nature, and ultimate submission to the social labyrinth.

2 Calvino's narrative ideology is a delicate balance between the axiological paradigm of reason/imagination which provides a two-fold flow to his discourse. The "corsi e ricorsi" (in a Vichian sense) of this model guarantees the perpetuity of his literary universe. Where reason dominates, man's ability to particularize and pulverize leads to revolutionary destruction; imagination, on the other hand, allows man to begin a new positive mythos. The parameters of Calvino's optimism and pessimism are thus totally dependent upon authorial intent and focus, i.e. the privileging of one mode over another.

3 Palomar's observations are a chain of spontaneous substitutions, compensatory supplements for a natural chaos which attempt to perversely rationalize a disconcerting, inherent lack of order in Nature. His metaphysical structures, however, and eventual, predestined conclusion, call to mind the apocalyptic speculations of Guglielmo da Baskerville of Umberto Eco's Il nome della rosa, (Milano: Bompiani, 1980): "Dove sta tutta la mia saggezza? Mi sono comportato da ostinato, inseguendo una parvenza di ordine, quando dovevo sapere bene che non vi è un ordine nell'universo." See p. 495.

4 This is "a world built by horizontal lines where words follow each other one at a time, and every paragraph occupies its orderly place, a world perhaps very rich, ever more rich than the unwritten one. . . " See Italo Calvino, "The Written and the Unwritten Word," The New York Review, 38-39 (12 May 1983), 38. The discontinuous interspace between these mutually exclusive worlds of the definitive, though illusory, written text and evolving, multiform reality is as permeable as it is prohibitive. For Palomar in "La contemplazione delle stelle," p. 44, "I frequenti confronti tra il cielo (external world) e la mappa (internal world of the page) lo obbligano ad accendere e spegnere la lampadina, e in questi passaggi dalla luce al buio egli resta quasi accecato e deve riaggiustare la sua vista ogni volta." For Calvino, the rite of passage is most traumatic: "When I move from the written world to the other, the one we currently call the world, based on three dimensions, five senses, peopled by four billions of our fellows, this means, for me, repeating every time the event of my birth, passing again through its trauma, to shape an intelligible reality from a lot of confused sensations, to choose again a strategy for facing the unexpected without being destroyed by it." The New York Review, cit., 38.

5 "Quel che la letteratura può fare è definire l'atteggiamento migliore per trovare la via d'uscita, anche se questa via d'uscita non sarà altro che il passaggio da un labirinto all'altro." See "La sfida al labirinto" in Una pietra sopra, p. 96. A more somber, less optimistic Calvino will later comment: "Nei confronti offertici dalla vita politica, ecomonica, sociologica il vecchio labirinto ci appare come un modello di una razionalità perduta." See "Come Snoopy anch'io mi sono perso," Tuttolibri (13 June 1981), 1.

6 Again we are reminded of Pirandello's "sentimento del contrario" and the atypical, almost abstract dimensions within which his megalomaniac characters perform, helplessly reside, obsessively meditate and acquiesce in silence (we are thinking especially of Enrico IV, Mattia Pascal, Vitangelo Moscarda, Serafino Gubbio). Both authors share an uneasy, vicarious existence through their characters, both share a definite affinity for transcendent relativism (though Calvino is prone to scepticism), both express the need for critical self-reflection and affirmation. "Io sto qui," a wry Calvino states in an interview granted to Costanzo Costantini, "io sto ancora qui, sono sempre io." See "E l'occhio scruta il caos del mondo," Il messaggero (31 dicembre, 1983), 3.

7 In the "Nota 1960" to I nostri antenati (Torino: Einaudi, 1960), pp. 353-61, Calvino postulates: "una persona si pone volontariamente una difficile regola, e la segue fino alle ultime conseguenze, perché senza di questa non sarebbe se stesso né per sé né per gli altri." See p. 356. 